\title{
Techno-economic analysis and environmental impact of biovalorization of agro-industrial wastes for biodiesel feedstocks by oleaginous yeasts
}

Saithip Sae-ngae ${ }^{1}$, Benjamas Cheirsilp ${ }^{2^{*}} \mathbb{D}$, Yasmi Louhasakul ${ }^{3}$, Thunwadee Tachapattaworakul Suksaroj ${ }^{4}$ and Punyanich Intharapat ${ }^{1}$

\begin{abstract}
Different types of agro-industrial wastes including lignocellulosic wastes, carbohydrate and protein-rich wastes, syrup wastes and glycerol wastes were explored as biodiesel feedstocks. This strategy not only can partially replace fossil fuel but also simultaneously decrease the environmental impact. This is the first report on the technoeconomic analysis and $\mathrm{CO}_{2}$ emissions of biovalorization of these wastes for biodiesel production by potential oleaginous yeasts. These evaluations could help to identify potential bottlenecks and suggest suitable implementations. Process models include steps of waste preparation, yeast cultivation, harvesting and biodiesel production through direct transesterification. The evaluation results reveal that the energy intensive steps which also have high $\mathrm{CO}_{2}$ emissions are the heating steps during waste preparation and sterilization prior to yeast cultivation. The most practical and cost-effective scenario was the recycling of glycerol waste from biodiesel industry as renewable feedstocks. This process not only reduces the production cost of biodiesel but also leads to a zero-waste discharge process with low $\mathrm{CO}_{2}$ emissions.
\end{abstract}

Keywords: Agro-industrial wastes, Biodiesel, Oleaginous yeast, Techno-economic analysis, Environmental impact

\section{Introduction}

Microbial oils produced by oleaginous microorganisms, are now considered as potential feedstocks for biodiesel production due to their similar fatty acid compositions to those of plant oils. The cultivation of oleaginous microorganisms as oil sources, has advantages over the production of plant oils because they have shorter life cycle, are affected neither by seasons nor climates, and much easier in scaling up [1]. Among available microorganisms, yeasts have higher potential over microalgae, fungi and bacteria, due to their unicellular relatively higher growth rate and higher oil content [2]. However,

\footnotetext{
* Correspondence: benjamas.che@psu.ac.th

${ }^{2}$ Faculty of Agro-Industry, Prince of Songkla University, Songkhla 90112, Thailand

Full list of author information is available at the end of the article
}

the production cost of microbial oil is still high due to the high cost of nutrient sources for cultivation. Therefore, most studies have focused on utilizing organic industrial wastes instead of high-grade nutrient sources [3, 4].

Although several industrial wastes have been explored for cultivation of the yeasts, there are still a lot of locally available and abundant wastes unexplored for this purpose. The suitability of the wastes as nutrient sources for the yeasts depends on the availability of carbon source and high carbon-to-nitrogen $(\mathrm{C} / \mathrm{N})$ ratio [4]. There are a number of agro-industrial wastes having high fermentable carbon source and high $\mathrm{C} / \mathrm{N}$ ratio. These include expired soft drinks (ES) from the carbonated soft drinks industry, solid wastes from brewing industry. As ES contains high amounts of sugars including glucose, fructose and sucrose, when left unsold and expired they cannot

(c) The Author(s). 2020 Open Access This article is licensed under a Creative Commons Attribution 4.0 International License, which permits use, sharing, adaptation, distribution and reproduction in any medium or format, as long as you give

appropriate credit to the original author(s) and the source, provide a link to the Creative Commons licence, and indicate if changes were made. The images or other third party material in this article are included in the article's Creative Commons licence, unless indicated otherwise in a credit line to the material. If material is not included in the article's Creative Commons licence and your intended use is not permitted by statutory regulation or exceeds the permitted use, you will need to obtain permission directly from the copyright holder. To view a copy of this licence, visit http://creativecommons.org/licenses/by/4.0/. 
be disposed directly into general wastewaters. The ES has to be stored in a storage tank before slowly released into the wastewater treatment system. Brewers' spent grains (BSG) are lignocellulosic parts of wort generated after mashing phase of beer production [5, 6]. BSG are generated at $15-20 \mathrm{~kg}$ per hectoliter of beer produced. Its total amount could be over $30 \mathrm{Mt}$ per year. Spent yeast cells (SYC) are the yeast cells separated after beer fermentation. They are abundant and low-cost biomass, rich in carbohydrate and protein [7-9]. Another organic waste, that has attracted special attention as it is an unavoidable by-product of biodiesel production, is crude glycerol (CG). The biodiesel industry generates approximately $10 \%(\mathrm{w} / \mathrm{w})$ of CG with every batch of biodiesel produced $[10,11]$. It has been reported that CG could be directly used by microorganisms without further purification [12]. As these wastes contain different chemical compositions, they could be classified into four categories including lignocellulosic waste (as in the case of BSG), carbohydrate and protein-rich waste (SYC), syrup waste (ES) and glycerol waste (CG).

The bioconversion of these wastes into biodiesel includes several crucial steps of waste preparation, yeast cultivation, harvesting of yeast cells, and transesterification of yeast oils into biodiesel. The yeast cultivation could be performed in stirred tank bioreactor with the controlled operating parameters such as temperature, $\mathrm{pH}$, agitation, and aeration rate. In addition to the yeast cultivation, the effective method for biodiesel production should be selected. Yeast oil can be converted into biodiesel by recently developed direct transesterification using acid catalyst in vigorously stirred tank reactor (VSTR). Louhasakul et al. [13] proposed the direct transesterification of yeast oils using wet cells in order to reduce the steps of cell drying and oil extraction and improve the conversion yield of yeast oils into biodiesel.

A number of techno-economic studies have been done on biodiesel production. However, most of them focused on microalgae as oil sources and only one study evaluated the use of oleaginous yeast cultivated on glucose as oil source [14]. There are several different substrates to choose for oil production by oleaginous yeasts. Some of those substrates have seriously restricted the development of industrialization. Nowadays, oil productions by the oleaginous yeasts are still in lab scale. More researches and development are required to establish an industrial route. It is necessary to study the crucial steps of the entire process. The techno-economic studies on biodiesel production from agro-industrial wastes using oleaginous yeasts have not been reported. It is expected that the use of renewable resources for energy production not only can partially replace fossil fuel but also simultaneously decrease the environmental impact. The energy usage and environmental impact of biofuels and fossil fuels were compared using life-cycle greenhouse gas (GHG) analysis in order to pursue sustainable biofuel production [15]. The methods for managing and reducing these emissions must be found and implemented. Renewable sources, such as biomass, may replace the use of all or part of those fossil fuels and have therefore contribution in reducing GHG emissions. The combined use of techno-economic and environmental impact assessment could be useful to provide information for policy makers and producers in identifying potential bottlenecks and choosing suitable implementations.

This study aimed to evaluate the techno-economic analysis and $\mathrm{CO}_{2}$ emissions for biovalorization of abundant agro-industrial wastes for biodiesel by potential oleaginous yeasts. Alternative processing scenarios were considered based on the waste preparation, yeast cultivation, harvesting and direct transesterification of yeast cells into biodiesel. The crucial steps involving in the industrial implementation of biovalorization were identified and the strategies to improve the techno-economic and environmental impact were proposed.

\section{Materials and methods \\ Waste preparation and yeast cultivation}

Two potent oleaginous yeasts, Rhodotorula mucilaginosa G43 and Trichosporonoides spathulata JU4-57 were obtained from Bioprocess Engineering Laboratory, Faculty of Agro-Industry (Prince of Songkla University, Thailand) and another oleaginous yeast Yarrowia lipolytica TISTR 5151 was from the Thailand Institute of Scientific and Technological (TISTR), Thailand. The stock cultures of the yeasts were inoculated into yeast extract peptone dextrose culture medium (glucose $10 \mathrm{~kg} \mathrm{~m}^{-3}$, peptone $5 \mathrm{~kg}$ $\mathrm{m}^{-3}$, yeast extract $3 \mathrm{~kg} \mathrm{~m}^{-3}$ ). The seed cultures were incubated at $30 \pm 2{ }^{\circ} \mathrm{C}$ and $200 \mathrm{rpm}$ for $24 \mathrm{~h}$.

In this study, the wastes from three agro-industries were used as nutrient sources for yeast cultivation. These include the wastes from carbonated soft drinks industry, brewery industry and biodiesel plant. ES were obtained from Haadthip Co. (Songkhla, Thailand). Its sugar concentration was in the range of $4-5 \%$. CG was obtained from the Biodiesel Plant (Faculty of Engineering, Prince of Songkla University, Thailand). CG based medium was prepared by adjusting $\mathrm{pH}$ to 6.0 and diluted to obtain glycerol concentration at $4 \%$. BSG and SYC from brewery industry were hydrolyzed using sulfuric acid and thermal treatment at $121^{\circ} \mathrm{C}$ for 20 min [9]. The BSG and SYC hydrolysate were neutralized using $10 \mathrm{~N}$ of $\mathrm{NaOH}$. All agro-industrial wastesbased media were added with $\mathrm{MgSO}_{4} \cdot 7 \mathrm{H}_{2} \mathrm{O} 0.2 \mathrm{~kg} \mathrm{~m}^{-3}$, $\mathrm{KH}_{2} \mathrm{PO}_{4} 0.5 \mathrm{~kg} \mathrm{~m}^{-3}$ and $\mathrm{CaCl}_{2} \cdot 2 \mathrm{H}_{2} \mathrm{O} 0.1 \mathrm{~kg} \mathrm{~m}^{-3}$ and $\mathrm{pH}$ adjusted to 6.0. The seed cultures were inoculated into sterilized medium and incubated at room temperature on rotary shaker at $140 \mathrm{rpm}$ for $72 \mathrm{~h}$. 


\section{Downstream processes}

The yeast cells after cultivation were harvested using centrifugation at $1585 \times \mathrm{g}$ for $15 \mathrm{~min}$. The yeast cells were washed using acetone and distilled water, then dried at $105^{\circ} \mathrm{C}$ for $5 \mathrm{~h}$ in hot air oven and then weighed to constant weight after cooling in a desiccator. Lipid extraction from dried biomass was performed according to the modified procedure of Bligh and Dyer [16]. The yeast oils were converted into biodiesel, namely fatty acid methyl esters (FAME) by transesterification and the compositions were determined using a HP6850 Gas Chromatograph equipped with a cross-linked capillary FFAP column (length 30 $\mathrm{m}, \quad 0.32 \mathrm{~mm}, 0.25 \mu \mathrm{m}$ film thickness) and a flame ionization detector. For the red yeast $R$. mucilaginosa G43, the carotenoids in its wet cells were extracted using acetone. Total nitrogen was measured by combustion method. Total sugar concentration was determined by the phenol-sulfuric acid method [17]. The sugar composition and acetic acid were analyzed with high-performance liquid chromatography using an Agilent Technology 1200 series Refractive Index Detector with an Aminex-HP-87H column operated at $65^{\circ} \mathrm{C}$ and mobile phase containing $0.05 \mathrm{M}$ of sulfuric acid pumped at a rate of $0.6 \mathrm{~mL} \mathrm{~min}^{-1}$. The glycerol concentration was determined using the method of Kosugi et al. [18].

\section{Estimation of biodiesel fuel properties}

The biodiesel fuel properties were calculated from empirical equations based on fatty acid compositions of yeast oils [9, 16]. These include saponification value $(\mathrm{SV})$, iodine value (IO), cetane number $(\mathrm{CE})$, and cold filter plugging point (CFP). The SV and IO were determined using Eqs. (1) and (2) as follows:

$$
\begin{aligned}
& \mathrm{SV}=\sum \frac{(560 \times F A M E)}{M W} \\
& \mathrm{IO}=\sum \frac{(254 \times D B)}{M W}
\end{aligned}
$$

where FAME represents individual FAME percentage by weight, $M W$ represents the molecular mass of individual FAME, and $D B$ represents number of double bonds in individual FAME.

Then, CE was determined using Eq. (3):

$$
\mathrm{CE}=46.3+\left(\frac{5458}{S A}\right)-(0.255 \times \mathrm{IO})
$$

Finally, long-chain saturation factor (LCS) and CFP were calculated using Eqs. (4) and (5) as follows:

$$
\begin{aligned}
\mathrm{LCS}= & (0.1 \times \mathrm{C} 16: 0+0.5 \times \mathrm{C} 18: 0+1 \times \mathrm{C} 20: 0+1.5 \\
& \times \mathrm{C} 22: 0+2 \times \mathrm{C} 24: 0)
\end{aligned}
$$

\section{Techno-economic and environmental impact analysis}

Laboratory data were used to validate the process flow and biodiesel yield from each agro-industrial waste. As several unit operations currently exist at commercial scale, the performance data for modeling and robust economic could be easily obtained. The constructed model would help to evaluate and analyze alternative processing methods and serve as the foundation for techno-economic analysis and calculations of $\mathrm{CO}_{2}$ emission.

\section{Techno-economic analysis}

This section begins by summarizing the options for microbial oil production from various industrial wastes followed by description of crucial steps including waste preparation, yeast cultivation, harvesting of yeast cells, and direct transesterification of yeast oils into biodiesel. The biomass and oil content of oleaginous yeasts cultivated on four wastes were compared and the suitable yeast for each waste was selected. The materials and utilities involved were listed and mass balances were employed for analysis of biodiesel yield. The models for biodiesel production from four agro-industrial wastes are listed as follows:

- Model I: bioconversion of lignocellulosic waste (BSG) into biodiesel.

- Model II: bioconversion of carbohydrate and proteinrich waste (SYC) into biodiesel.

- Model III: bioconversion of syrup waste (ES) into biodiesel.

- Model IV: bioconversion of glycerol waste (CG) into biodiesel.

A scale factor of $1 \mathrm{~m}^{3}$ was used and the capacity was selected based on an economic case study where the specific investment cost reaches a constant value. All the values are presented in US\$. The preliminary economic analysis of biodiesel production from agro-industrial wastes had been conducted mainly based on the operating costs involving in bioconversion processes from wastes into yeast oils and hence biodiesel. Therefore, the installation and equipment costs have been not taken into account in this analysis. The operating costs are estimated based on typical industrial-scale operation.

\section{Environmental impact analysis}

As energy requirements and GHG emission are two main environmental factors during bioconversion process, these two factors were then considered to evaluate bioconversion 
process of four different wastes into yeast oil and hence biodiesel. The primary GHG emissions considered in this study are carbon dioxide. The emissions and environmental impact of the bioconversion of each agro-industrial waste were quantified through the metric of global warming potential (GWP). The GHG potential factors measure how much a given mass of GHG contributes to global warming, in comparison to carbon dioxide. This allows summary carbon dioxide equivalent $\left(\mathrm{CO}_{2}\right.$-eq) units of all the emissions together and allows the direct comparisons between different scenarios. There are four steps for the life cycle assessment (LCA) methodology according to the ISO 14000 series (ISO 14041-43) including (1) goal and scope definition; (2) inventory analysis; (3) impact assessment; and (4) interpretation.

(1) Goal and scope definition The aim and scope of this study is to determine the environmental impact of biodiesel production using oleaginous yeasts grown on agro-industrial wastes and to determine which model has a greater environmental impact. This study does not cover the entire life cycle (cradle-to-grave) evaluation of the product, but rather it studied a gate-to-gate system boundary beginning with the waste preparation, yeast cultivation, harvesting (integrated lab-scale) and biodiesel production (lab-scale with estimated energy requirements) and did not get to the end of life process (disposal). Overall goal of the preliminary study was to compare life cycle $\mathrm{CO}_{2}$. The functional unit for this system boundary is $1 \mathrm{~kg}$ biodiesel. Figure 1 shows life cycle system boundary of the oil production by oleaginous yeasts and subsequent biodiesel production through direct transesterification. The other phases of use, disposal and transportation of the products are omitted in this study. The $\mathrm{CO}_{2}$ emissions were investigated from Models I, II, III and IV.

(2) Inventory analysis The results of the LCA environmental impact have been quantified in relation to the functional unit. The functional unit provides a reference that relates inputs and outputs. The inventory data for the biodiesel production were collected and calculations were made to quantify the input from the environment and the output to the environment. This study focused on resources usage, energy usage, chemical, wastes and by-products from biodiesel production. Almost all LCA carried out on microorganisms to date have looked at the direct process related impacts from microorganisms with none fully considering indirect effects [19].

The system boundary and LCA study are according to the following parameters:

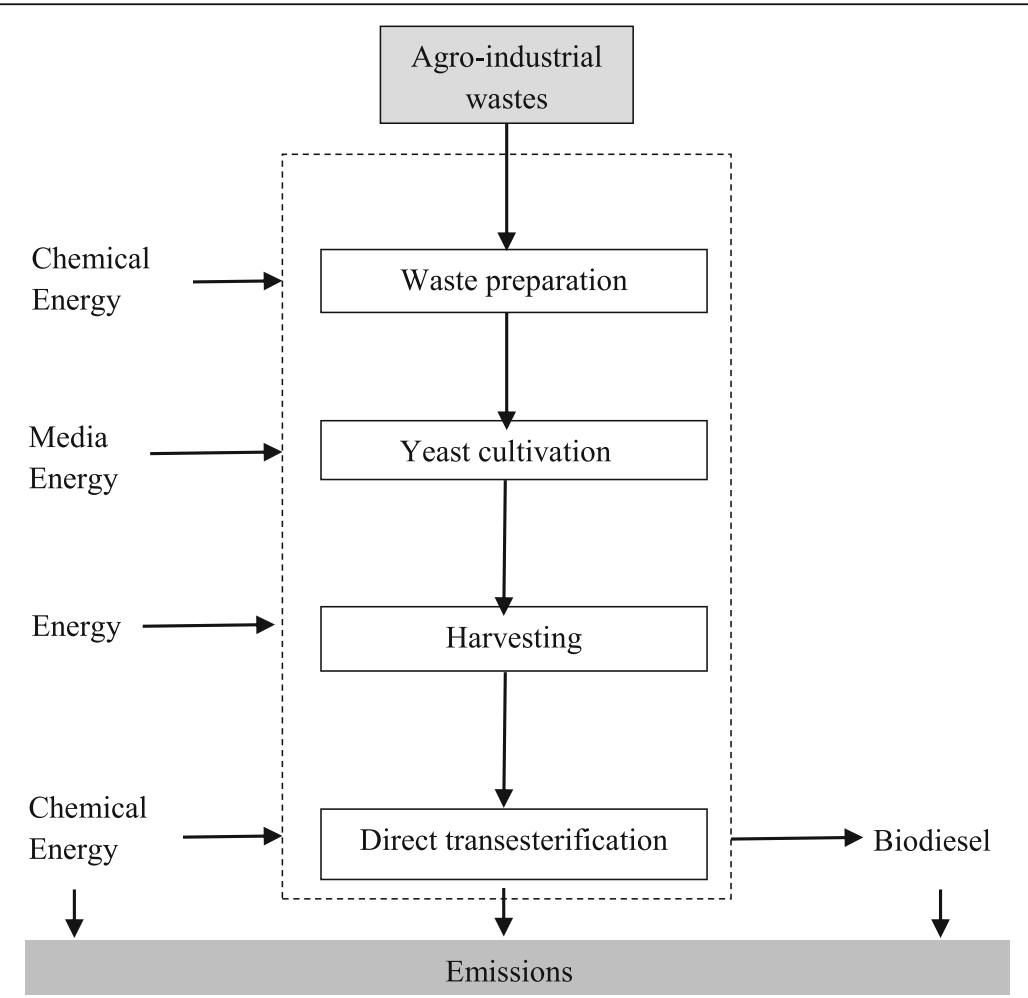

Fig. 1 Life cycle system boundary of the lipid production by oleaginous yeasts and subsequent biodiesel production through direct transesterification 
- From gate-to-gate, start from waste preparation and ends with biodiesel production as the main product.

- Biodiesel production from yeast oils is carried out via direct transesterification.

- Main energy inputs will be included throughout the life cycle.

- Emissions of wastewater and other types of air pollutants during biodiesel production are not covered in the LCA but more information could be found in the literature [20].

(3) Impact assessment The impact of GHG emissions in terms of $\mathrm{CO}_{2}$ would create the same amount of warming. The GHG emissions then can be expressed as $\mathrm{CO}_{2}$ emissions from a carbon footprint of all processes. This is necessary to undertake detail of the life cycle calculations of the processing energy needed to make the biodiesel production, in order to quantify the GHG emissions at each stage of the process of environmental impact. The GHG was calculated in units of $\mathrm{CO}_{2}$-eq using the GWP values according to the 2006 IPCC Guidelines for National GHG Inventories [21] and aggregated using Intergovernmental Panel on Thailand GHG Management Organization; GHG emission = activity data $\times$ emission conversion factor.

(4) Interpretation The interpretation of the environmental impact, a normalization step relates the indicator values to reference values. The results and recommendations were analyzed, concluded and explained during the interpretation phase in accordance with the results of the previous LCA phases [22, 23].

\section{Results and discussion}

\section{Overview on process flow for bioconversion of agro-} industrial wastes into biodiesel

In this study, there are four crucial steps for biodiesel production from agro-industrial wastes by oleaginous yeasts including waste preparation, oleaginous yeast cultivation, harvesting of yeast cells, direct transesterification of yeast oils into biodiesel as illustrated in Fig. 1.

\section{(1) Waste preparation}

Among four wastes, ES could be directly used without treatment while CG needed $\mathrm{pH}$ adjustment prior to yeast cultivation. Other two solid wastes (BSG and SYC) needed to be hydrolyzed into fermentable sugars before use. This process requires higher chemical and energy costs than those for liquid wastes. Several types of acids, concentrated or diluted, can be used, including sulfurous, sulfuric, hydrochloric, hydrofluoric, phosphoric, nitric and formic acids. Among them, sulfuric acid has been extensively used due to its high catalytic activity and low cost. The optimal acid concentration used for acid hydrolysis process was in the range of $1-10 \%$ and at the temperature between 100 and $150^{\circ} \mathrm{C}$ [24-27].

\section{(2) Yeast cultivation}

The use of industrial wastes as cheap source of nutrients for oleaginous yeasts has been considered as a costeffective way to produce biodiesel feedstocks [28]. The yeast cultivation was performed and the experimental data obtained was used for designing for the production in one batch. The agitation and aeration were operated to continuously supply the oxygen. The cultivation was run until the yeast cell growth reached to late log phase. The models are designed by configuring technically viable as well as least cost equipment options as much as possible.

\section{(3) Harvesting}

Commonly used harvesting technologies are flocculation, filtration and centrifugation. Flocculation method requires the addition of flocculent to flocculate suspended cells into pellets. However, these flocculent are difficult to be removed and may cause contamination during downstream processes. Filtration method requires membrane filter and is prone to membrane fouling effects which lead to decrease in the performance. Centrifugation uses centrifugal separation to harvest the cells without applying other chemical reagents. The advantage of centrifugation is fast harvesting [20]. Although, there are a number of available techniques for harvesting of the microorganisms, the most commonly used harvest methods for the oleaginous cells are still the centrifugation [29].

\section{(4) Direct transesterification}

Microbial oils can be converted into biodiesel by transesterification reaction using alkaline or acid catalysts. The developed direct transesterification of yeast oil into biodiesel using wet cells can reduce the steps of drying and oil extraction and hence improve the productivity and cost-effectiveness. Recently, the VSTR was designed and the important parameters for direct transesterification of yeast oil into biodiesel were optimized by Louhasakul et al. [13]. As this study did not perform the direct transesterification of the yeast oils, the experimental data from Louhasakul et al. [13] were used for calculation.

\section{Experimental data from lab scale Waste characterization and preparation}

This study aimed to use four agro-industrial wastes as low-cost nutrient sources for yeast cultivation. The availability of carbon sources in the wastes and $\mathrm{C} / \mathrm{N}$ ratio are crucial factors affecting the performance of the yeast to grow and accumulate oil. In many cases, high $\mathrm{C} / \mathrm{N}$ ratio can promote the oil accumulation in the yeast cells as energy reserve materials. However, too high $\mathrm{C} / \mathrm{N}$ ratio, 
namely very low nitrogen, will limit the cell propagation and restrict biomass production. The low biomass concentration will lead to the low overall oil production.

BSG is a lignocellulosic waste that contained $24.5 \%$ hemicellulose, $20.9 \%$ cellulose and 9.6\% lignin. BSG also contained protein at a high level of $23.1 \%$. After acid hydrolysis, the BSG hydrolysate contained sugars of $33 \mathrm{~kg}$ $\mathrm{m}^{-3}$ and total nitrogen of $1.2 \mathrm{~kg} \mathrm{~m}^{-3}$ which corresponded to relatively low $\mathrm{C} / \mathrm{N}$ ratio of 11 . The sugar compositions in BSG hydrolysate were xylose $(45.8 \%)$ and arabinose (32.1\%) from hemicellulose and glucose $(22.0 \%)$ from cellulose. SYC is rich in both protein and carbohydrate at 46.9 and $21.3 \%$, respectively. The SYC hydrolysate was composed of sugars at $62 \mathrm{~kg} \mathrm{~m}^{-3}$ and total nitrogen of $7.02 \mathrm{~kg} \mathrm{~m}^{-3}$ which corresponded to very low $\mathrm{C} / \mathrm{N}$ ratio of 3.53 . It was found that mannose $(69.6 \%)$ and glucose (31.4\%) are the main sugar types found in SYC hydrolysate which released from mannan and $\beta$ glucan, respectively.

Another two wastes are liquid wastes, ES and CG, which could be used directly without acid hydrolysis. ES contained high amount of sugars $\left(48.0 \mathrm{~kg} \mathrm{~m}^{-3}\right)$ including fructose $59.8 \%$, glucose $27.5 \%$ and sucrose $12.7 \%$. The nitrogen concentration was only $0.135 \mathrm{~kg} \mathrm{~m}^{-3}$ which corresponded to very high $\mathrm{C} / \mathrm{N}$ ratio of 142 . CG comprised of $32.4 \% \mathrm{w} / \mathrm{v}$ glycerol and $1.86 \mathrm{~kg} \mathrm{~m}^{-3}$ nitrogen which corresponded to moderately high $\mathrm{C} / \mathrm{N}$ ratio of 68 . The $\mathrm{pH}$ of CG was as high as 9 because the alkali was used as catalyst during biodiesel production. It should be noted that the recycling of CG from biodiesel plant for oil production by the yeasts not only reduces the production costs of oil feedstocks but also contributes to the zero-waste strategy. The CG not only has advantages as low-cost carbon source for microbial fermentation but also reduces glucose repression present in case of glucose utilization [30].

\section{Yeast cultivation}

The types of carbon source and $\mathrm{C} / \mathrm{N}$ ratio in the wastes are the main factors affecting yeast cell growth and oil production. It is necessary to select the best combination of the wastes with the yeasts for efficient bioconversion of these wastes into oil sources. The suitable yeasts for each waste were screened. Table 1 summarizes the performance of the most potent three yeasts cultivated on each agro-industrial waste for $72 \mathrm{~h}$. All oleaginous yeasts grew well on BSG hydrolysate and reached comparable final biomass of $6-7 \mathrm{~kg} \mathrm{~m}^{-3}$. The oil content in three yeasts ranged from 8 to $20 \%$. Similarly, all yeasts also grew well on SYC hydrolysate and reached the biomass of $4.0-4.8 \mathrm{~kg} \mathrm{~m}^{-3}$ with the oil content of 14 to $20 \%$. Compared to SYC hydrolysate, BSG hydrolysate was considered as more suitable nutrient source for yeast cell growth likely due to the suitable sugar compositions (xylose, arabinose and glucose) for yeast assimilation. Among the yeasts tested, T. spathulata JU4-57 was considered as the most suitable yeast for bioconversion of BSG hydrolysate into oils while Y. lipolytica TISTR 5151 was considered as the most suitable yeast for bioconversion of SYC hydrolysate into oils.

ES was a good nutrient source for cell growth and biomass production by oleaginous yeast $R$. mucilaginosa G43 (Table 1). It was possible that $R$. mucilaginosa G43 could assimilate fructose, the main sugar found in ES, better than the other two yeasts. However, Y. lipolytica TISTR 5151 was more suitable for oil production from ES due to its higher oil content $(25.1 \pm 5.8 \%)$ than $R$. mucilaginosa G43 (10.1 $\pm 2.9 \%)$. It should be noted that only $R$. mucilaginosa G43 could grow well on CG with very high oil content of $50-63 \%$. These levels were much higher than those cultivated on other three wastes. It could be concluded that among the wastes and the

Table 1 Bioconversion of agro-industrial wastes into biomass with high oil content

\begin{tabular}{llll}
\hline $\begin{array}{l}\text { Agro-industrial wastes } \\
\text { (sugar composition) }\end{array}$ & Oleaginous yeasts & Biomass $\left(\mathrm{kg} \mathrm{m}^{-3}\right)$ & Oil content $(\%)$ \\
\hline $\begin{array}{l}\text { Brewers' spent grain hydrolysate } \\
\text { (xylose 45.8\%, arabinose 32.1\%, glucose 22.0\%) }\end{array}$ & T. spathulata JU4-57 & $20.1 \pm 3.1$ \\
& R. mucilaginosa G43 & $7.35 \pm 0.22$ & $8.8 \pm 3.4$ \\
& Y. lipolytica TISTR 5151 & $7.60 \pm 0.05$ & $14.2 \pm 4.1$ \\
Spent yeast cell hydrolysate & T. spathulata JU4-57 & $6.78 \pm 0.13$ & $19.4 \pm 4.5$ \\
(mannose 69.6\%, glucose 31.4\%) & R. mucilaginosa G43 & $4.07 \pm 0.03$ & $14.4 \pm 4.9$ \\
& Y. lipolytica TISTR 5151 & $4.33 \pm 0.10$ & $20.9 \pm 3.3$ \\
Expired soft drinks & T. spathulata JU4-57 & $4.78 \pm 0.10$ & $20.6 \pm 11.9$ \\
(fructose 59.8\%, glucose 27.5\%, sucrose 12.7\%) & R. mucilaginosa G43 & $1.40 \pm 0.28$ & $10.1 \pm 2.9$ \\
& Y. lipolytica TISTR 5151 & $5.20 \pm 0.77$ & $2.7 .1 \pm 5.8$ \\
Crude glycerol & T. spathulata JU4-57 & $2.70 \pm 0.05$ & $52.9 \pm 8.6$ \\
(glycerol 32.4\%) & R. mucilaginosa G43 & $2.12 \pm 0.10$ & $5.12 \pm 0.10$ \\
& Y. lipolytica TISTR 5151 & $1.45 \pm 0.23$ & $63.7 \pm 4.7$ \\
\hline
\end{tabular}


yeasts tested, $R$. mucilaginosa G43 cultivated on CG was the best combinations for oil production. In addition to oils, $R$. mucilaginosa G43 also contained high value pigment-carotenoids at $15 \mathrm{~g} \mathrm{~kg}^{-1}$ yeast and protein at $165 \mathrm{~g} \mathrm{~kg}^{-1}$ yeast. This yeast then has high potential not only as microbial oil sources but also as pigment and protein sources.

\section{Biodiesel properties of yeast oils}

Another important criterion for being used as biodiesel feedstocks is the fatty acid composition of the yeast oils. This is because biodiesel properties are directly influenced by fatty acid compositions of the oil sources. Conversion of the yeast oils to FAMEs followed by GC analyses revealed the fatty acid composition of the yeast oils as shown in Table 2. The oils from T. spathulata JU4-57 cultivated on BSG hydrolysate and oils from $Y$. lipolytica TISTR 5151 cultivated on SYC hydrolysate and ES, were mainly composed of long-chain fatty acids with 16 and 18 carbon atoms including oleic acid as the predominant fatty acid (47-56\%) followed by linoleic acid (15-30\%) and palmitic acid (approximately 15\%). It should be also noted that the fatty acids of Y. lipolytica TISTR 5151 oils were mainly unsaturated fatty acids (63-77\%) which would show the excellent cold flow properties. While the oils from $R$. mucilaginosa G43 cultivated on CG were mainly palmitic acid (approximately $40 \%)$ followed by oleic acid (26\%), linoleic acid (20\%). These results indicate that the fatty acid compositions of the yeast oils mainly depend on the yeast strains. The similar fatty acid compositions of yeast oils to those of plant oils indicate their potential use as alternative feedstocks for biodiesel. The oil compositions of the oleaginous yeasts in this study were also similar to those previously reported. The oils from $R$. mucilaginosa TJY15a which was grown on hydrolysate of cassava starch were mainly composed of palmitic acid and oleic acid higher than 85\% [31]. Rhodosporidium toruloides ATCC 10788 also contained mainly palmitic acid and oleic acid when using CG as a substrate [10].

Several major properties of biodiesel can be estimated from fatty acid compositions of oil sources. These are SV, IO, CE, LCS, and CFP [32]. Table 2 also shows the estimated biodiesel properties from the fatty acid compositions of yeast oils. The SV represents mg of $\mathrm{KOH}$ needed to saponify $1 \mathrm{~g}$ of oil. A low SV indicates a high percent of long chain fatty acids in the oils. The SV of yeast oils were $201-208 \mathrm{mg} \mathrm{KOH} \mathrm{g} \mathrm{oil}{ }^{-1}$ which were similar to those of oleaginous yeasts [33]. The IO is the mass of iodine that reacts with $100 \mathrm{~g}$ of oil. It depends on both the number and position of double bonds in the oil and it shows the tendency of biodiesel to react with oxygen. The IO of yeast oils were $63-85 \mathrm{~g} \mathrm{I}_{2} 100 \mathrm{~g}^{-1}$ oil which meet the European standard EN-14214 (not exceeding $120 \mathrm{~g} \mathrm{I}_{2} 100 \mathrm{~g}^{-1}$ oil). CE is considered as the main parameter indicating biodiesel quality. It represents the ignition quality of a diesel fuel. In a particular diesel engine, the fuels with high $\mathrm{CE}$ will have shorter ignition delay than fuels with low CE. For most diesel engines, a value above 40 is acceptable. It should be noted the $\mathrm{CE}$ of all yeast oils are above 40. The important parameter for low temperature applications of a fuel is CFP. The

Table 2 Fatty acid compositions (\%) and biodiesel properties of yeast oils

\begin{tabular}{lllll}
\hline $\begin{array}{l}\text { Fatty acid } \\
\text { compositions/ }\end{array}$ & BSG & SYC & ES & CG \\
Biodiesel properties & T. spathulate JU4-57 & Y. lipolytica TISTR 5151 & Y. lipolytica TISTR 5151 & R. mucilaginosa G43 \\
\hline Myristic acid (C14:0) & 0.3 & 0.2 & - & 1.9 \\
Palmitic acid (C16:0) & 13.5 & 10.3 & 15.4 & 40.5 \\
Palmitoleic acid (C16:1) & 1.6 & 2.2 & 8.8 & 2.7 \\
Stearic acid (C18:0) & 5.7 & 3.3 & 7.0 & 4.7 \\
Oleic acid (C18:1) & 53.3 & 47.0 & 52.8 & 26.9 \\
Linoleic acid (C18:2) & 22.3 & 30.6 & 15.9 & 20.6 \\
Linolenic acid (C18:3) & 1.3 & - & - & 1.2 \\
Lignoceric acid (C24:0) & 0.3 & - & - & 0.9 \\
Saturated fatty acids & 19.9 & 13.9 & 22.5 & 47.9 \\
Unsaturated fatty acids & 78.4 & 79.8 & 77.5 & 51.3 \\
SA & 201.9 & 202.1 & 203.4 & 208.3 \\
IO (g I I $^{100} \mathrm{~g}^{-1}$ ) & 93.4 & 99.9 & 85.1 & 68.5 \\
CE & 49.5 & 47.8 & 51.4 & 55.0 \\
LCF (wt\%) & 4.4 & 2.7 & 5.1 & 6.5 \\
CFP ( ${ }^{\circ}$ C) & -2.7 & -7.9 & -0.6 & 3.9
\end{tabular}

SA saponification value; $1 O$ iodine value; $C E$ cetane number; $L C F$ long-chain saturation factor; CFP cold-filter plugging properties: $<0$ (summer) $<-10$ (winter) 
CFP is used to predict the behavior of the biodiesel at the low temperature. The cloud point is the temperature at which wax first becomes visible when the fuel is cooled. The pour point is the lowest temperature at which the oil specimen can still be moved [34]. Based on the fatty acid profiles of yeast oils, it could be concluded that the oleaginous yeasts derived biodiesel would have the properties meeting the biodiesel standards and could be used as a substitute for petroleum-based diesel fuel. Among the wastes and the yeasts tested, $R$. mucilaginosa G43 growing on CG could be considered as the most suitable oil feedstock for biodiesel production. This was because it could give relatively high CE (55) and acceptable CFP (3.9) compared with those from other yeasts growing on other wastes. These properties were likely due to the high content of saturated fatty acids of $R$. mucilaginosa G43 when growing on CG.

\section{Technical performance of each model}

The technological processes of bioconversion of four agro-industrial wastes were evaluated to fulfill their requirement for industrial scale application. The investigations were made to see the efficient and affordable technological options for biodiesel production from industrial wastes. Four models for four agro-industrial wastes are studied. Models I and II are the bioconversion of lignocellulosic waste (BSG) and carbohydrate and protein-rich waste (SYC) into biodiesel. Models III and IV are the bioconversion of syrup waste (ES) and glycerol waste (CG) into biodiesel. The detail process flows of each waste are as follows:

Models I and II: Fig. 2 shows the process flow diagram describing the detail of chemicals and energy involved in bioconversion of BSG and SYC into biodiesel in $1 \mathrm{~m}^{3}$ scale. The process started with acid hydrolysis with thermal treatment at temperature $121^{\circ} \mathrm{C}$ for $20 \mathrm{~min}$ and subsequent neutralization using sodium hydroxide. Based on the amount of sugar obtained after acid hydrolysis, the amount of acid and sodium hydroxide required was varied. Prior to yeast cultivation, other nutrients were added. The cultivation conditions were set to be: initial cell concentration of $0.5 \mathrm{~kg} \mathrm{~m}^{-3}$ in stirred tank bioreactor at room temperature $\left(30 \pm 2{ }^{\circ} \mathrm{C}\right)$ for $72 \mathrm{~h}$. Based on these conditions, the energy required for yeast cultivation was estimated.

The data of biomass and oil production were obtained from lab scale experiment in Table 1. After oleaginous yeast cultivation on industrial wastes in bioreactor, the yeast cell mass was harvested by centrifugation at $1585 \times \mathrm{g}$ for $15 \mathrm{~min}$. The harvested yeast cells were assumed to be directly used in transesterification without drying [13]. The wet yeast cells were then introduced to $30 \mathrm{~L}$ VSTR. The glass beads were added as cell disrupting agents at the bead weight to biomass weight ratio of
1:1. The methanol was added as oil extracting solvent and feedstock at the ratio of 4:1 (v/w). The sulfuric acid was used as catalyst for transesterification at $2 \%(\mathrm{v} / \mathrm{v})$ in methanol. The mixture was vigorously mixed at 1000 rpm. The reaction temperature was set at $50^{\circ} \mathrm{C}$. After reaction for $1 \mathrm{~h}$, the reaction mixture was centrifuged. The biodiesel layer was recovered and the methanol was separated by evaporator. It should be noted that the conversion efficiency mainly depends on the operating conditions for direct transesterification of yeast cells in VSTR [13]. Therefore, the conversion efficiency of oils in yeast cells into biodiesel (97\%) was referred from the previous study [13]. Hence, the direct transesterifications of $1.5 \mathrm{~kg} \mathrm{~m}^{-3}$ and $0.71 \mathrm{~kg} \mathrm{~m}^{-3}$ of yeast oils from BSG and SYC hydrolysate were expected to produce 1.46 and $0.68 \mathrm{~kg}$ biodiesel $\mathrm{m}^{-3}$, respectively.

The total energy input required for Models I and II were $87.3 \mathrm{kWh}$ (sum of energy input in Fig. 2). It seemed that heating operation in acid hydrolysis (conversion from solid into liquid) and sterilization appeared to be the most energy intensive stages which accounted for $80 \%$ of total energy input. It should be noted that the combined sterilization process with acid hydrolysis process could reduce energy input by $40 \%$. Moreover, the use of nonsterile wastes could be beneficial to reduce energy input and consequently operating cost of bioconversion process. It has been reported that it is possible to use non-sterile media for yeast cultivation [35]. The generated biomass residues could be sold as animal feed and/or used as renewable feedstocks for further microbial fermentation. Moreover, the generated by-product from transesterification process, CG, at $10 \%$ of produced biodiesel could also be either sold at the market or used as renewable feedstocks for yeast cultivation and this then finally could offset the production cost of the biodiesel.

Models III and IV: the process flow diagrams describing bioconversion of ES and CG into biodiesel are shown in Fig. 3. The ES could be directly used without pretreatment while $\mathrm{CG}$ required hydrochloric acid for $\mathrm{pH}$ adjusting from 9 to 6 . For yeast cultivation, $Y$. lipolytica TISTR 5151 was the most suitable oleaginous yeast for ES conversion into oils while $R$. mucilaginosa G43 was the most suitable oleaginous yeast for CG conversion into oils (Table 1). The cultivation conditions were: initial cell concentration of $0.5 \mathrm{~kg} \mathrm{~m}^{-3}$ in stirred tank bioreactor at room temperature $\left(30 \pm 2{ }^{\circ} \mathrm{C}\right)$ for $72 \mathrm{~h}$. The centrifugation was used for harvesting the yeast cells at $1585 \times \mathrm{g}$ for $15 \mathrm{~min}$. The conditions for direct transesterification of yeast oils in biodiesel are the same as those described in Models I/II. The biodiesel achieved from $Y$. lipolytica TISTR 5151 cultivated on ES was $0.64 \mathrm{~kg}$ and that from $R$. mucilaginosa G43 cultivated on CG was $2.02 \mathrm{~kg}$. The total energy input required for Models III and IV were $52.39 \mathrm{kWh}$ (sum of energy input in Fig. 3). 


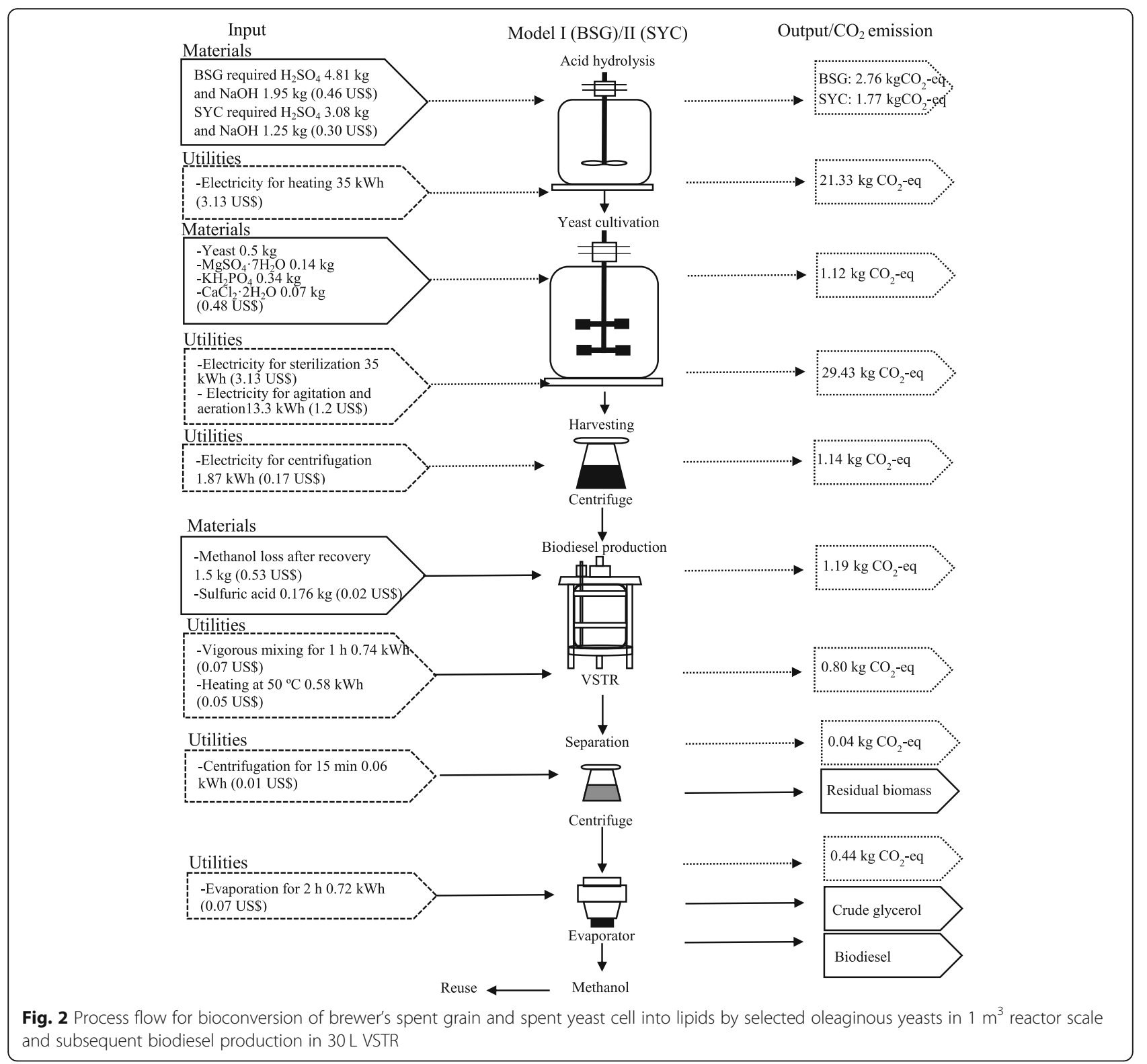

Among the four models evaluated, Model IV could give the highest biodiesel in $1 \mathrm{~m}^{3}$ scale at $2.02 \mathrm{~kg}$ followed by Model I $(1.46 \mathrm{~kg})$, Model II $(0.68 \mathrm{~kg})$, with Model III producing the lowest biodiesel $(0.64 \mathrm{~kg})$. Therefore, Model IV showed the lowest energy demand per $1 \mathrm{~kg}$-biodiesel at $25.9 \mathrm{kWh}$. The highest energy consumption was by acid hydrolysis and cultivation approximately $69-89 \%$ of total energy demand. It was due to the heating operation required. Therefore, the energy consumptions by Models I and II were much higher than those by Models III and Model IV.

\section{Economic assessment}

Economically viable biofuel should be cost competitive with petroleum fuels. There are many factors that involve in the high production cost of microbial based biodiesel [36]. Specifically, the cost of substrate or carbon source required approximately $60-75 \%$ of the total costs of the biodiesel production. Therefore, the economics of microbial based biodiesel can be improved by using low-cost nutrients in agro-industrial wastes. Another important aspect in microbial based biodiesel is the efficiency and economic feasibility to achieve an economical and sustainable production. Figure 4 indicates operating cost categories including materials and utilities involved in waste preparation, yeast cultivation, harvesting and direct transesterification. From the overall cost analysis in each model, the total operating cost of Models I and II were highest at 9.18-9.34 US\$ followed by Model IV (6.06 US\$) and Model III (5.73 US\$). The 


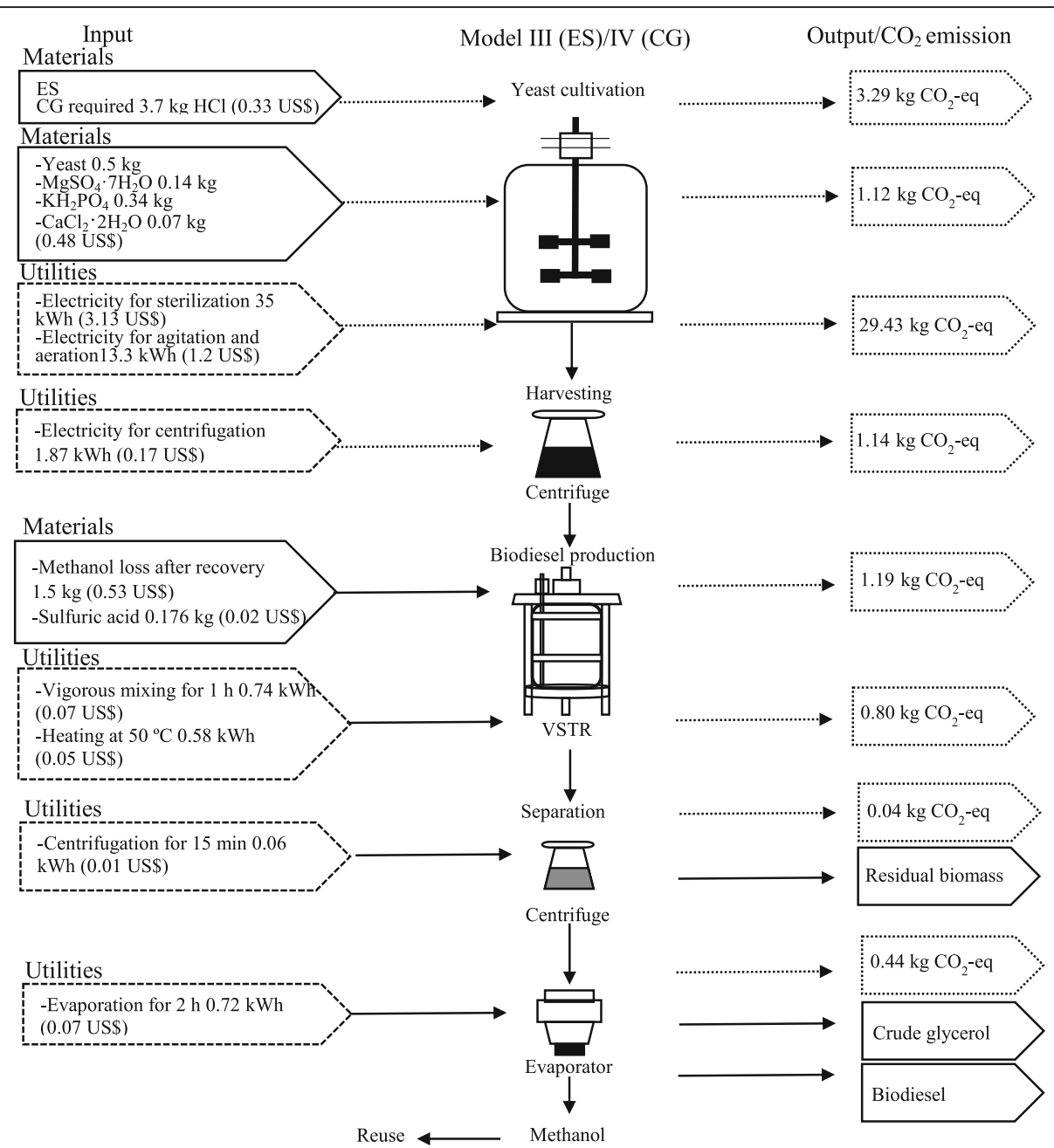

Fig. 3 Process flow for bioconversion of liquid wastes into lipids by appropriate oleaginous yeasts in $1 \mathrm{~m}^{3}$ reactor scale and subsequent biodiesel production in $30 \mathrm{~L}$ VSTR
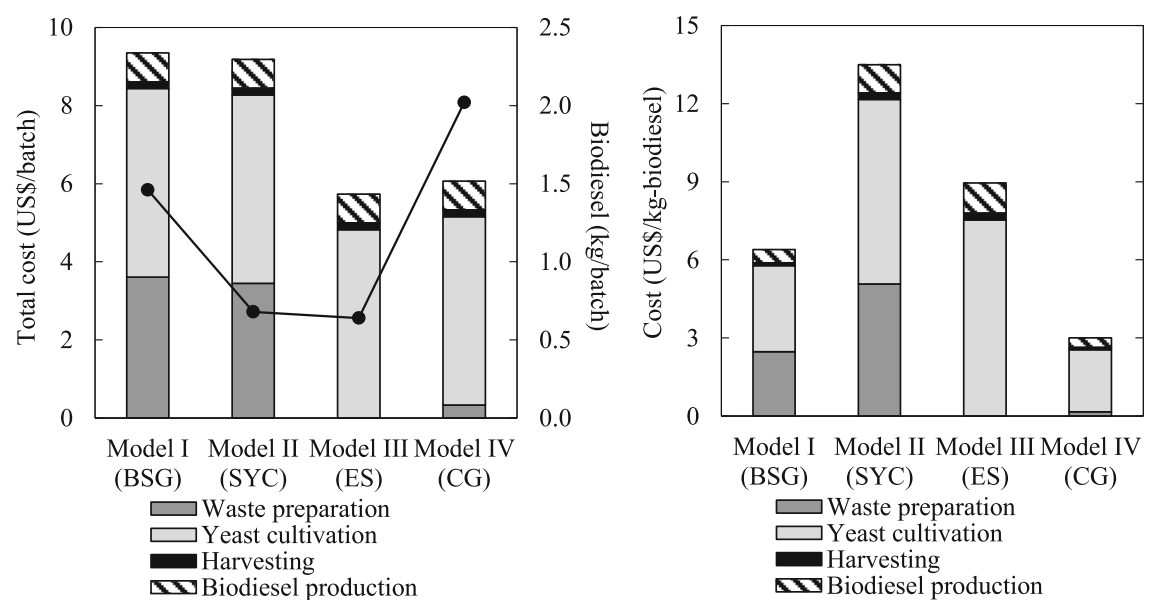

Fig. 4 Comparison of total operating cost and cost per $1 \mathrm{~kg}$-biodiesel of bioconversion of agro-industrial wastes into biodiesel. Symbols with line represent biodiesel yield 
high cost for biodiesel production in Models I and II was due to the energy cost for heating in acid hydrolysis process during waste preparation step. As no acid hydrolysis is needed in Models III and IV, the energy costs of these two processes were much lower. Comparing between two solid wastes, BSG has higher economic potential than SYC due to the higher yield of biodiesel obtained. Among four models, Model IV required the lowest operating cost per $1 \mathrm{~kg}$-biodiesel at $3.0 \mathrm{US} \$$. It is also interesting to note that carotenoids and protein in R. mucilaginosa G43 could be sold back to the market as high-value products and can then contribute as significant revenues. Moreover, CG generated as side streams in the biodiesel production process could also be recycled as renewable feedstocks for yeast cultivation and subsequent biodiesel production. It should be noted that the cost analysis in this study was based on only one product, biodiesel. These models would be more economical viable if the generated biomass residues and by-products could be sold.

The economics of biodiesel production from microbial oils relate to the cost-competitive feedstocks and technologies used in the process. In this study, the bioconversion of crude glycerol waste by oleaginous yeast $R$. mucilaginosa G43 in Model IV was considered as the most economical process for biodiesel production as this process required the lowest operating cost of biodiesel at 3.0 US\$ $\mathrm{kg}^{-1}$ which was about 3-5 times lower than that using high grade nutrients $\left(10-15\right.$ US $\left.\$ \mathrm{~kg}^{-1}\right)$. As this waste required less steps and equipment than the wastes in Models I and II, the capital recovery cost associated with installation and equipment would also be lower. The biodiesel production from microbial oils in this study showed high potential for industrial implementation due to their competitiveness in costs and contribution to zero-waste from industries. Other studies have reported the biodiesel production costs from microalgal oils in the range of 2.59-5.42 US\$ $\mathrm{kg}^{-1}[37,38]$. While Alabi et al. [39] and Ratledge and Cohen [40] have reported the relatively high production costs for oil from microalgae in the range of $7.64-21$ US\$ $\mathrm{kg}^{-1}$. For comparison to those production costs, information on capital costs shall be collected and evaluated further.

\section{Environmental impact}

GHG emissions occur during the fermentation process and in the life cycle of biodiesel generation. These GHG emissions have certain environmental results. Therefore, the LCA of biodiesel production must be evaluated in order to find the environmental hotspots and to produce biofuels with substantially less GHG emissions than the fossil derived fuels [19]. The net GHG was determined leveraging the inputs and outputs of the engineering process model with life cycle inventory data. In this study, GHG emissions expressed as $\mathrm{CO}_{2}$ emissions from each step in bioconversion of agro-industrial wastes into biodiesel are shown in Figs. 2 and 3. Figure 5 summarizes the pioneer $\mathrm{CO}_{2}$ emissions from each model of biodiesel production. The $\mathrm{CO}_{2}$ emissions from Models I and II (57-58 $\mathrm{kg} \mathrm{CO}_{2}$-eq) are much higher than those from Models III and IV (35-37 $\mathrm{kg} \mathrm{CO}_{2}$-eq). It was obvious that the $\mathrm{CO}_{2}$ equivalents of the input chemicals were much lower than those of heating operation during acid hydrolysis in Models I and II (Fig. 2) and during sterilization in all models. The $\mathrm{CO}_{2}$ emissions from these two processes are approximately $65-86 \%$ of total $\mathrm{CO}_{2}$ emissions. Alternative scenarios should be considered to reduce the environmental impact. The combined process of acid hydrolysis with sterilization and the use of non-sterile process may greatly contribute to potential
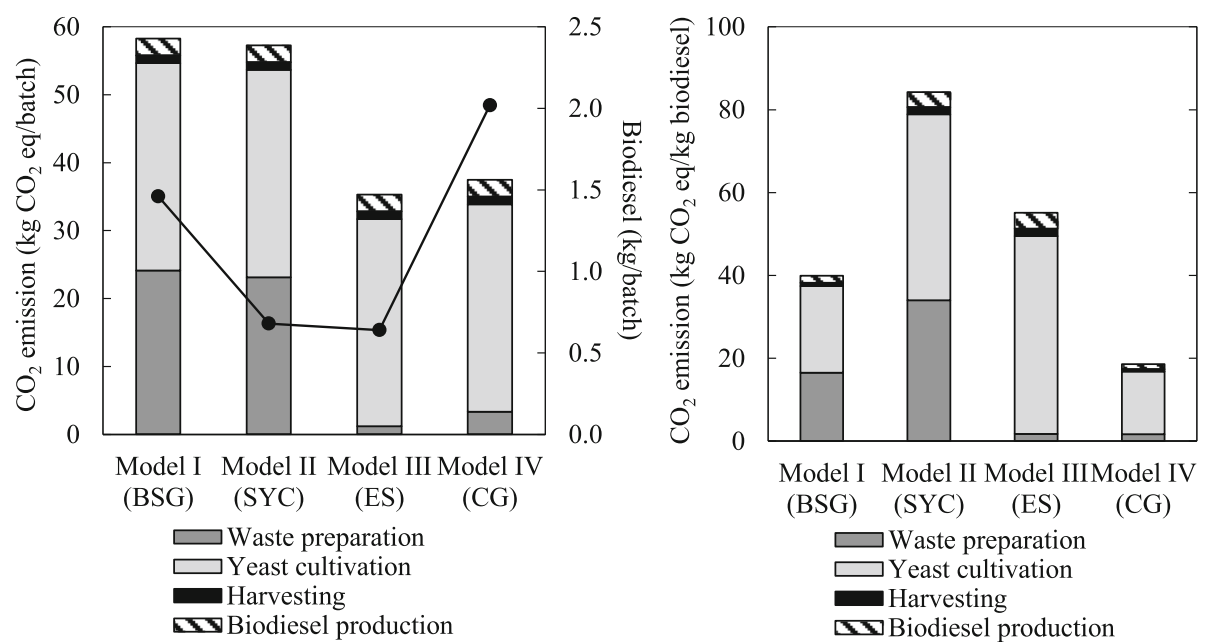

Fig. 5 Comparison of total $\mathrm{CO}_{2}$ emission and $\mathrm{CO}_{2}$ emission per $1 \mathrm{~kg}$-biodiesel of bioconversion of agro-industrial wastes into biodiesel. Symbols with line represent biodiesel yield 
reduction in emissions. Another strategy could be the co-product utilization and optimization.

\section{Conclusions}

This study has shown that four types of agro-industrial wastes could be converted into biodiesel. Among the wastes tested, expired soft drinks representative for syrup wastes could be used directly without any pretreatment and this contributes to the lowest cost required and the lowest $\mathrm{CO}_{2}$ emission. Solid wastes from brewery industry need acid hydrolysis and thermal treatment to soluble nutrients and this process requires much intensive energy and causes the highest $\mathrm{CO}_{2}$ emissions. Glycerol waste from biodiesel industry was not suitable for yeast cell growth but it gave the highest oil production and biodiesel yield. The techno-economic analysis suggests that the use of glycerol waste as biodiesel feedstocks gives the highest profitability with the lowest environmental impact per $1 \mathrm{~kg}$-biodiesel. The recycling of glycerol waste as renewable feedstocks not only reduces the production cost of biodiesel and $\mathrm{CO}_{2}$ emissions but also leads to a zero-waste process and promote the circular economy.

\section{Authors' contributions}

SS designed, conducted the experiments, analyzed the data and drafted the manuscript. BC designed, analyzed the data, and proved the manuscript. YL, TTS and PI analyzed the data and commented on the manuscript. All authors read and approved the final manuscript.

\section{Funding}

This research was financially supported by the Graduate School of Prince of Songkla University, and the National Research Council of Thailand. The second author was supported by Thailand Research Fund Grant No. RTA6280014.

\section{Availability of data and materials}

The datasets analyzed during the current study are available from the corresponding author on reasonable request.

\section{Competing interests}

The authors declare that they have no competing interests.

\section{Author details \\ ${ }^{1}$ Faculty of Environmental Management, Prince of Songkla University, Songkhla 90112, Thailand. ${ }^{2}$ Faculty of Agro-Industry, Prince of Songkla University, Songkhla 90112, Thailand. ${ }^{3}$ Faculty of Science Technology and Agriculture, Yala Rajabhat University, Yala 95000, Thailand. ${ }^{4}$ ASEAN Institute for Health Development, Mahidol University, Nakhon Pathom 73170, Thailand.}

Received: 24 October 2019 Accepted: 1 May 2020

Published online: 08 June 2020

\section{References}

1. Li YH, Zhao ZB, Bai FW. High-density cultivation of oleaginous yeast Rhodosporidium toruloides Y4 in fed-batch culture. Enzyme Microb Tech. 2007:41:312-7

2. Meng X, Yang JM, Xu X, Zhang L, Nie QJ, Xian M. Biodiesel production from oleaginous microorganisms. Renew Energ. 2009;34:1-5.

3. Soccol CR, Neto CJD, Soccol VT, Sydney EB, da Costa ESF, Medeiros ABP, et al. Pilot scale biodiesel production from microbial oil of Rhodosporidium toruloides DEBB 5533 using sugarcane juice: performance in diesel engine and preliminary economic study. Bioresour Technol. 2017;223:259-68.
4. Arous F, Frikha F, Triantaphyllidou IE, Aggelis G, Nasri M, Mechichi T. Potential utilization of agro-industrial wastewaters for lipid production by the oleaginous yeast Debaryomyces etchellsii. J Clean Prod. 2016; 133:899-909.

5. Celus I, Brijs K, Delcour JA. The effects of malting and mashing on barley protein extractability. J Cereal Sci. 2006:44:203-11.

6. Vieira EF, da Silva DD, Carmo H, Ferreira IMPLVO. Protective ability against oxidative stress of brewers' spent grain protein hydrolysates. Food Chem. 2017;228:602-9

7. Mussatto SI, Dragone G, Roberto IC. Brewers' spent grain: generation, characteristics and potential applications. J Cereal Sci. 2006;43:1-14.

8. Niemi P, Martins D, Buchert J, Faulds CB. Pre-hydrolysis with carbohydrases facilitates the release of protein, from brewer's spent grain. Bioresour Technol. 2013;136:529-34.

9. Ryu BG, Kim J, Kim K, Choi YE, Han JI, Yang JW. High-cell-density cultivation of oleaginous yeast Cryptococcus curvatus for biodiesel production using organic waste from the brewery industry. Bioresour Technol. 2013;135:357-64.

10. Uprety BK, Dalli SS, Rakshit SK. Bioconversion of crude glycerol to microbial lipid using a robust oleaginous yeast Rhodosporidium toruloides ATCC 10788 capable of growing in the presence of impurities. Energ Convers Manage. 2017;135:117-28.

11. Chen JX, Zhang XL, Yan S, Tyagi RD, Drogui P. Lipid production from fedbatch fermentation of crude glycerol directed by the kinetic study of batch fermentations. Fuel. 2017;209:1-9.

12. Qin L, Liu L, Zeng AP, Wei D. From low-cost substrates to Single Cell Oils synthesized by oleaginous yeasts. Bioresour Technol. 2017;245:1507-19.

13. Louhasakul Y, Cheirsilp B, Maneerat S, Prasertsan P. Direct transesterification of oleaginous yeast lipids into biodiesel: development of vigorously stirred tank reactor and process optimization. Biochem Eng J. 2018;137:232-8.

14. Koutinas AA, Chatzifragkou A, Kopsahelis N, Papanikolaou S, Kookos IK. Design and techno-economic evaluation of microbial oil production as a renewable resource for biodiesel and oleochemical production. Fuel. 2014; 116:566-77.

15. Wang MQ, Han J, Haq Z, Tyner WE, Wu M, Elgowainy A. Energy and greenhouse gas emission effects of corn and cellulosic ethanol with technology improvements and land use changes. Biomass Bioenergy. 2011; 35:1885-96

16. Bligh EG, Dyer WJ. A rapid method of total lipid extraction and purification. Can J Biochem Phys. 1959:37:911-7.

17. Dubois M, Gilles KA, Hamilton JK, Rebers PA, Smith F. Colorimetric method for determination of sugars and related substances. Anal Chem. 1956;28: 350-6.

18. Kosugi $Y$, Kunieda $T$, Azuma N. Continual conversion of free fatty acid in rice bran oil to triacylglycerol by immobilized lipase. J Am Oil Chem Soc. 1994; 71:445-8.

19. Collet P, Helias A, Lardon L, Steyer JP, Bernard O. Recommendations for Life Cycle Assessment of algal fuels. Appl Energ. 2015;154:1089-102.

20. Chauhan SK, Shukla A. Environmental impacts of production of biodiesel and its use in transportation sector. In: Bernardes MADS, editor. Environmental impact of biofuels. London: IntechOpen; 2011.

21. IPCC. IPCC guidelines for National Greenhouse gas Inventories. Hayama: Intergovernmental Panel on Climate Change; 2006. p. 2006.

22. Brentrup F, Kusters J, Kuhlmann H, Lammel J. Environmental impact assessment of agricultural production systems using the life cycle assessment methodology: I. theoretical concept of a LCA method tailored to crop production. Eur J Agron. 2004;20:247-64.

23. Chen J, Li Q, Chang C, Bai J, Liu L, Fang S, et al. Techno-economic analysis of biodiesel production from microalgae: a review. Trend Renew Energ. 2017;3:141-52.

24. Galbe M, Zacchi G. A review of the production of ethanol from softwood. Appl Microbiol Biot. 2002;59:618-28.

25. Chiaramonti D, Prussi M, Ferrero S, Oriani L, Ottonello P, Torre $P$, et al. Review of pretreatment processes for lignocellulosic ethanol production, and development of an innovative method. Biomass Bioenergy. 2012;46:25-35.

26. Wingren A, Galbe M, Zacchi G. Techno-economic evaluation of producing ethanol from softwood: comparison of SSF and SHF and identification of bottlenecks. Biotechnol Prog. 2003;19:1109-17.

27. Lenihan P, Orozco A, O'Neill E, Ahmad MNM, Rooney DW, Walker GM. Dilute acid hydrolysis of lignocellulosic biomass. Chem Eng J. 2010;156:395-403. 
28. Louhasakul Y, Cheirsilp B. Industrial waste utilization for low-cost production of raw material oil through microbial fermentation. Appl Biochem Biotech. 2013;169:110-22

29. Xia CJ, Zhang JG, Zhang WD, Hu B. A new cultivation method for microbial oil production: cell pelletization and lipid accumulation by Mucor circinelloides. Biotechnol Biofuels. 2011:4:15.

30. Cheirsilp B, Louhasakul Y. Industrial wastes as a promising renewable source for production of microbial lipid and direct transesterification of the lipid into biodiesel. Bioresour Technol. 2013;142:329-37.

31. Li M, Liu GL, Chi Z, Chi ZM. Single cell oil production from hydrolysate of cassava starch by marine-derived yeast Rhodotorula mucilaginosa TJY15a. Biomass Bioenergy. 2010;34:101-7.

32. Schleicher T, Werkmeister R, Russ W, Meyer-Pittroff R. Microbiological stability of biodiesel-diesel-mixtures. Bioresour Technol. 2009;100:724-30.

33. Xu JY, Zhao XB, Wang WC, Du W, Liu DH. Microbial conversion of biodiesel byproduct glycerol to triacylglycerols by oleaginous yeast Rhodosporidium toruloides and the individual effect of some impurities on lipid production Biochem Eng J. 2012;65:30-6.

34. Ramos MJ, Fernandez CM, Casas A, Rodriguez L, Perez A. Influence of fatty acid composition of raw materials on biodiesel properties. Bioresour Technol. 2009;100:261-8.

35. Santamauro F, Whiffin FM, Scott RJ, Chuck CJ. Low-cost lipid production by an oleaginous yeast cultured in non-sterile conditions using model waste resources. Biotechnol Biofuels. 2014:7:34

36. Subramaniam R, Dufreche S, Zappi M, Bajpai R. Microbial lipids from renewable resources: production and characterization. J Ind Microbiol Biot 2010;37:1271-87.

37. Davis R, Aden A, Pienkos PT. Techno-economic analysis of autotrophic microalgae for fuel production. Appl Energ. 2011;88:3524-31.

38. Richardson JW, Johnson MD, Outlaw JL. Economic comparison of open pond raceways to photo bio-reactors for profitable production of algae for transportation fuels in the southwest. Algal Res. 2012;1:93-100.

39. Alabi AO, Tampier M, Bibeau E. Microalgae technologies \& processes for biofuels/bioenergy production in British Columbia: current technology, Suitability \& Barriers to implementation. British Columbia Innovation Council: Vancouver; 2009.

40. Ratledge C, Cohen Z. Microbial and algal oils: do they have a future for biodiesel or as commodity oils? Lipid Technol. 2008;20:155-60.

\section{Publisher's Note}

Springer Nature remains neutral with regard to jurisdictional claims in published maps and institutional affiliations.

Ready to submit your research? Choose BMC and benefit from:

- fast, convenient online submission

- thorough peer review by experienced researchers in your field

- rapid publication on acceptance

- support for research data, including large and complex data types

- gold Open Access which fosters wider collaboration and increased citations

- maximum visibility for your research: over $100 \mathrm{M}$ website views per year

At $\mathrm{BMC}$, research is always in progress.

Learn more biomedcentral.com/submissions 